$\xi=$

\title{
Linear Landscape Spaces in the Planning Structure of the City
}

\author{
Luidmyla Shevchenko $^{1 *}$, Natalia Novoselchuk ${ }^{2}$, Volodymyr Toporkov ${ }^{3}$ \\ ${ }^{1}$ Poltava National Technical Yuri Kondratyuk University, Ukraine \\ ${ }^{2}$ Poltava National Technical Yuri Kondratyuk University, Ukraine \\ ${ }^{3}$ Poltava National Technical Yuri Kondratyuk University, Ukraine \\ *Corresponding Author E-Mail: Ls.Shevchenko@Ukr.Net
}

\begin{abstract}
The article is aimed to show up the role of linear landscape spaces in the layout structure of a city. The current urban environment of existence of human shows a mix between nature, urbanized informative space, advanced innovative technologies, design elements. The authors accentuate importance of creation harmonious ecological and esthetically attractive environment of a city for human life and activities basing on the proper compatibility of these constituents. Basing on the selected methodology of research the authors analyze the available historiography material, world analogues of the investigated objects and their project conceptions. The article presents the existing theoretical conceptions of the urban development starting from the treatises of the ancient Greek philosophers up to project urban conceptions of the future cities basing on the linear landscape spaces. Position of the objects under research is outlined in the system of the green space. The system includes the objects under investigation as its integral part. The authors are educed the most widespread varieties of objects. The authors show the most widespread varieties of objects under research in the layout structure of modern cities. Particular attention of the authors is addressed to the linear parks, embankments, boulevards and parkways that play an important role in life and activity of a city and its habitants. Importance of proper implementation of project conceptions for such spaces has been shown by means of different spheres of design - landscape, ecological, ergonomics, urban and graphic.
\end{abstract}

Keywords: Linear landscape space, linear park, embankment, parkway, boulevard.

\section{Introduction}

The ancient Greek scientist Aristotle noticed in his time, that a "city must be built in such a way, so as to provide safety and happiness to its habitants" [1, p. 166]. These keywords become very actual in our time, when cities more than ever turn into the large urbanized "mechanisms" with the accumulated facilities, artificial elements, cluttered by activity, noise, unfinished streams of machines and people. Fewer and fewer the new towns offer crisp air, greenery, reservoirs, open spaces. Are people happy to live in such cities? The human at subconscious level stores association with the natural environment of any quality of cities in the whole, its district, particular quarter or certain landscape area.

The growing number of scientists is convinced that only studying intercommunication of natural phenomena and human life allows to project a corresponding harmonious physical environment for human being. The current environment of human existence is a mix between nature, urbanized informative space, advanced innovative technologies, elements of design. The landscape-townplanning conceptions based on the relevant cooperation of the above constituents provide creation of the harmonious ecologically and esthetically attractive environment of a city, in accordance with ideology of the ecological urbanism. The brick and concrete stark walls of building, paved horizontal surfaces, glass and mirroring vertical elements must be acceptable "neighbours" for the park open-spaces, public gardens, embankments with waterways, avenues and terraces with flowering plants and other areas of greenery. As the well-known landscape architect J. Simonds witnessed in his time "such urban spaces, as oases are able to convert a city into the absolutely new landscape that really becomes an attractive, refreshing environment" [1, p. 166].

The urban areas of greenery include the linear landscape objects that run through a city in various directions, forming relatively narrow but prolonged stripes of plantations. They encircle the certain areas of city and create the protective green barriers. They encirle the waterways of a city, maintaining the atmosphere and harmony of natural environment. All of them as a whole are the integral part of the system of the urban area of greenery. The system unites them into composition and architectural-planning way and provides the social-functional requirements of people in everyday short-time rest, directs the people to the urban attractive public objects or forest-park and off-shore stripes, unites them on common usable space. Therefore the linear landscape spaces deserve particular research and attention of scientists and specialists from the point of view of their influence on formation of the harmonious urban environment which is able to provide happy life to its habitants.

\section{Research Methodology}

During examination of these objects the authors used empiric and theoretical methods. Assemblage and processing of the available data base as for linear landscape spaces and their systematization became the first step in the process of accumulation of the required information. Existent historical, architectural and literary sources, scientific works of previous researchers and architecturalproject materials have been systematized after the basic constituents. Materials relating to the spatial and planning urban organization, particularly its composition-aesthetic constituents and land- 
scape organization have been abstracted from the data base. V. Glazichev, D. Alisova, M. Barkhin, A. Gutnov, E. Izvarin, A Rappaport and other carried out researches under philosophical, sociological and culturological aspects relating to the urban culture, idealizations of the urban beliefs. The scientist S. Mikhaylov has devoted great care to the urban design. Researches of $\mathrm{O}$. Koleman, O. Nioman, C. Gabidulina, T. Dridze, R. Grigoryants, L. Kogan, A. Krashennikov, V. Melnikov and other are devoted to investigations of improvement of methods of study and adjusting of social problems of cities. The works of Y. Lantsberg, A. Urbah, L. Tverskaya, I. Romanovsky were devoted to the urban linear space.

Among a number of researchers of urban spatial organization the special mention should go to R. Venturi, K. Linch [2], A. Brickman [3], V. Glazichev, V. Shimka et al. Their important works allow to investigate the linear landscape space in the general spatial structure of cities. Landscape organization of urban environment in whole became the object of research by J. Simonds, L. Zalesskaya, I. Rodichkina [4], L. Vergunova [5], V. Kucheryavy, N. Kryzhanivska, O. Mikulina, A. Belkin et al. Partly their researches touch upon the linear landscape urban space. The architectural-composition and aesthetic descriptions of certain structural urban components (including objects of this research) can be found in works by A. Vergunov, C. Sitte [6], M. Belov [7], D. Bruks, V. Petrov, B. Vipper, G. Zemger, Z. Gideon, L. Naimov, V. Kandinsky, A. Bunin, T. Savarenskaya [8], Z. Yarhina et al. These works give an opportunity to trace the scientific search of forming conceptions of landscape objects in order to create the integral harmonious environment.

The advanced studies of linear landscape spaces of city are aimed at organization of their object and spatial environment by synthesis of design with other types of project-art activity such as townplanning, architecture, landscape and graphic design, monumental and decorative art [7]. Special mention should go to the advanced scientists, because their dissertation researches, scientific publications are related to the above mentioned subjects. Thanks to the extended abstracts of dissertations, scientific discoveries in professional editions (including foreign ones), we have the opportunity to estimate level of solution of problematic and consequently - to outline questions remained beyond attention of scientists or insufficiently sorted out on local space. These are works of O. Smolenskaya, O. Kalinina, E. Ponomareva, M. Siverc, C. Chepurna, M. Dutsaev et al. Great significance among historiography materials is presented by the operating state normative documents.

It is to be noted that required information appears periodically in professional foreign magazines and home professional scientific editions. Analysis of the existent historiography material allows critically to estimate work of previous scientists and outline the package of unsettled issues and materials for the advanced processing. The further processing of materials is based on the historical-factual and monographic methods. The first relates to research of facts from history of town-planning in whole and singly taken linear landscape spaces in particular. The second method assists the detailed deep study of certain objects under research. The topographical method is under special scientific interest. It is based on work with supporting materials - layout schematics, general layouts of cities and especially on their fragments. They allow to investigate the parameters of linear landscape spaces (both in structure of the cities in whole and at local level), character of their structural constituents (relief, water elements, vegetable material and others like that)

The process of accumulation of factual material is not limited only by the study of historiography materials. The integral part of this process is a visual inspection of objects under research. In order to fix the existent state of landscape territories drawings and watercolors pictures are executed from the most attractive and interesting specific points. They give an approximate idea about the object. The most exact documentary image of an object is provided by photos that justify authenticity and correctness of the applied research methods.
Funds of the National Library of Ukraine n.a. V.I. Vernadskyi (Kyiv), Kharkiv Scientific State Library n.a. V.G. Korolenko, Scientific Libraries of the Poltava National Technical Yuri Kondratuk University (Poltava) and Poltava V.G. Korolenko National Pedagogical University (Poltava), Scientific Library n.a. I. Kotlyarevsky (Poltava), materials of the reference-information fund of the Research Institute of Theory, History of Architecture and Town-Planning (Kyiv) are processed and used in this paper.

\section{Linear Landscape Spaces in Theoretical Town-Planning Conception}

In course of certain periods of development of theoretical conceptions in town-planning scientists tried to find balance between artificial and natural objects in cities, to create the city of future, comfort for its habitants. It is interesting to note that a number of theoretical ideas is based on use of the linear landscape spaces as green arteries that run through a city linearly, radially and around circle. The ancient Greek philosopher Plato in his treatises described an ideal society being in close intercommunication of every living things with their environment on the example of the city-state on island of Atlantida. The detailed description allows to assume placing of open-space by narrow circles, between the built-up territories. After many centuries similar ideas formed the basis for Italian ideal cities-fortresses of XV-XVI centuries.

Aggravation of the ecological and social-economic problems in cities during XX century resulted in appearance of new ideas for cities of the future. The "city-garden" of E. Howard (Fig.1, a) is the interesting example of such ideas. Conception of the city included linear landscape spaces: internal and external circular avenues and radial system of boulevards. This conception was realized in the cities-gardens of Letchworth in 1904 and Welwyn Garden City in 1920 (Great Britain, Fig. 1, b, c) Later, in 1961 the similar conception of development of cities was presented by the well-known landscape architect J. Simonds. His idea of city consisted in the circular placing of park territories and cruciform green avenues (Fig 1, d). At the beginning XX of century the French architect T. Garniet offered conception of the ideal industrial city. It was the first proposal for this city to use the linear landscape space as a sanitary-hygienic zone between industrial territory and housing building.
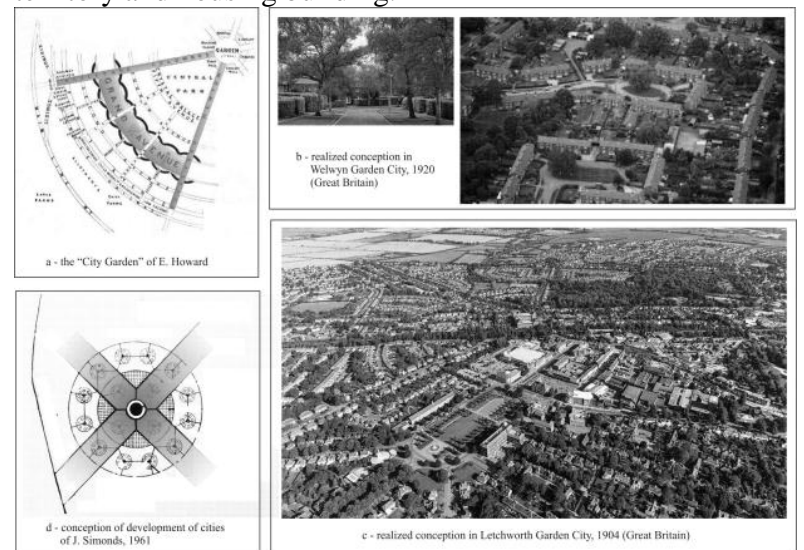

Fig. 1: New ideas for cities of the future. Theoretical conceptions of the XX century.

From the point of view of this research special attention should go to conception of creation of linear cities. First such idea has been proposed by engineer A. Soria y Mata as early as in 1882. According to the author's idea the extended form of city was stretched out along the transport artery. All structural constituents of such city had a linear structure, including system of green plantations. Such idea of linear city was continued in the ideas of soviet scientists A. Milutin, O. Ladovsky, I. Leonidov. A linear city by A. Milutin consists of parallel stripes of railway road, industrial and housing zones, linear green belt for rest, highway and park. In 1930 the 
team of architects worked out variants of a planned structure of Magnitogorsk as a linear city (by the layout of O. Ladovsky).

Realization of plan of Abercrombi and enactment about new cities (New Towns Act, 1946) became a precursor in development of town-planning conceptions. These new cities in Great Britain envisaged green belt with the forest planting, green territories for activity and area for agricultural lands [9]. Project proposals on development of South Hampshire and Nort Buck (Fig. 2) that proposed to inculcate the wide long stripes of landscape spaces are the examples of such conceptions.

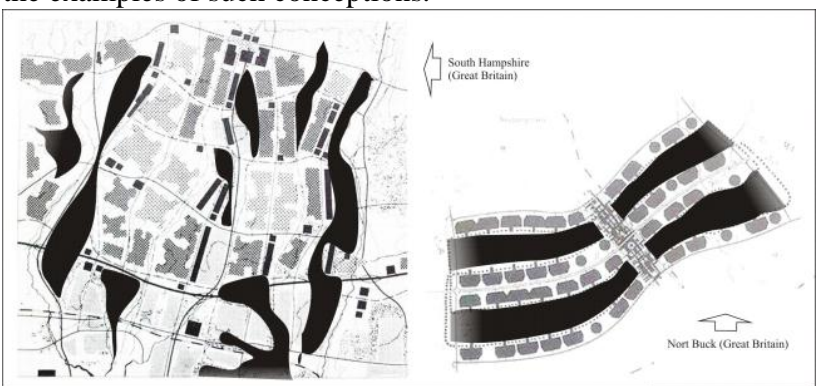

Fig. 2: New cities of Great Britain according to the plan of Abercrombi.

Interesting is experience of other European countries in the formation of urban linear landscape spaces, in development of new territories, improvement of the existing towns and projects for new cities. The projects of district planning of Amsterdam and Rotterdam (Netherlands) involved the system of greenspace in the form of long V-shaped zones between the housing quarters (Fig. 3, a). Projects of new cities in France contain conception of continuity of urban landscape intended to create the harmonious urban environment. Shining example of this conception is the project proposed for Evri, where the picturesque stripes of green plantations run though the whole city. Proposal of transformation of SergyPontoise in a resort city is grounded not only by the existent forest planting but also because of offered linear green stripes that connect existent arrays of greenery (Fig. 3, b).
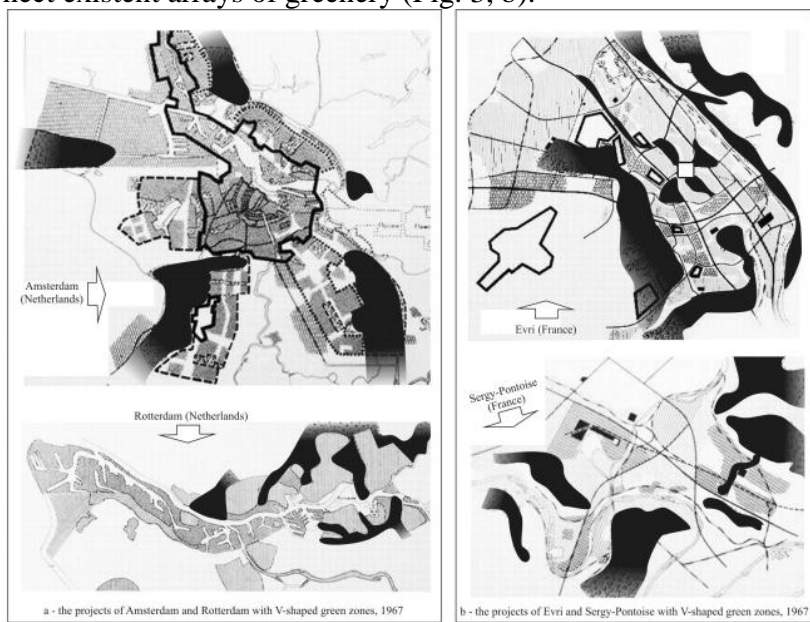

Fig. 3: Projects of new cities in the European countries in the formation of urban linear landscape spaces.

The end of XX of century showed to the world the real threat to the planetary ecosystem in whole because of industrial cities, pollution of environment, urbanization processes. The scientists of all countries of the world began to carry out the active ecological prognostication. Advantage of the ecological factor of development over the economic one became evident. At town-planning level this is resulted in appearance of number of projects of cities of the future, different in some way from the previous futuristic analogues (Fig. 4). Project of reconstruction of Athens (Greece) is based on the network of greenery belts in its central part. The number of green spots (parks, public gardens and others like that) is laid over the main linear landscape space. Planning idea of the city "Venus" by J. Fresco is similar to that by E. Howard. Radially-circular layout allows to form narrow circular stripes of greenery around the center. The city Masdar (OAE) is picturesquely run through by the number of linear landscape spaces that connect artificial waterways and planting of greenery on its peripheral areas. Several projects of new cities became to be implemented into life.

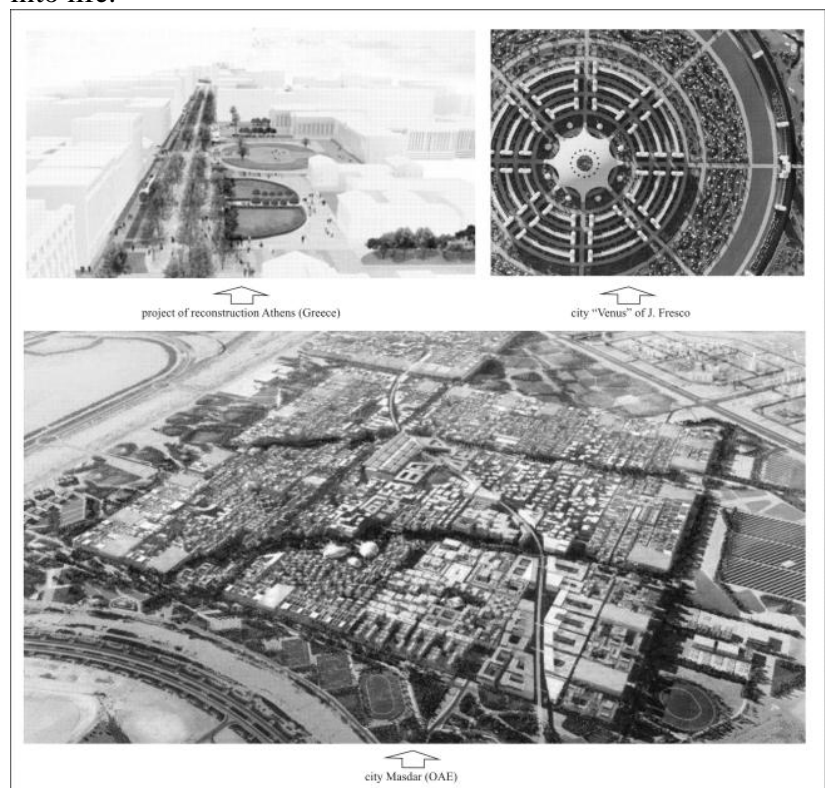

Fig. 4: Modern projects of cities of the future with urban linear landscape spaces.

\section{Linear Landscape Spaces in the Planning Structure of Modern Cities}

Organization of harmonious comfort spaces in the structure of the new urbanized cities, conditioning for social rest of habitants of policies is the important task of present time not only for architects-urbanists but also for urban landscape architects and designers, common city people. Because the place of a human being in such spaces changes in course of time, following the changes of parameters and concepts as for the comfort of object and spatial environment. Today new high-comfort urban spaces which run through town-planning framework and connect the important public and cultural and historical magnets for citizens, creating green corridors from housing arrays up to the forest-park zones and waterways appear under conditions of existence of technogenic civilization.

Objects under research are the integral part of the system of the planted land of a city. From one side it is determined by segmentation of city by the plan elements and from other side the system stipulates its layout structure. Development of such system in cities provides balance in its town-planning structure, acceptable sanitary-hygenic norms and aesthetic constituent. The continuous system of the planted lands is responsible for the equitability of intercity landscape open-space. The authors analyzed a number of theoretical models of placing of the planted lands worked out by previous scientists [4]. It is educed that the major part of these models is based exactly on development of linear landscape spaces and their combinations. Among such models are V-shaped, circular, peripherally-linear, diametrically-linear, transversal-tract and longitudinally-tract issues. Combined models such as peripherally-V-shaped, linear-V-shaped and core-radial (Fig. 5) give bitter effect. Such models are actively implemented in the townplanning structure as a system of green V-shaped zones, waterpark line, linear-tract and radially-circular systems and their combinations (see Fig. 5).

Importance of development of such spaces is repeatedly underlined by scientists that try to find principles and means of their organization in accordance with the modern level of urban culture of XXI century. Comfort and attractive space must have the functionally reasonable planning, original designer conception keeping in mind the ecological constituents, ergonomics parameters, intercommunication with the town-planning system. Because in our time such spaces serve not only as urban interior spaces but also as 
a platform for environment experiments, related to integration of natural elements, to approbation of modern technological novelties. Landscape compositions, elements of urban design, sculpturaldecorative and supergraphic compositions, street furniture and advertising media, system of visual communications and various temporal installations participate in their development. Such spaces must be accessible for all habitants of a city. The important aspect of their availability for all categories of population is their barrier-free structure. The structure of the new urban linear landscape spaces includes rampants, escalators, lifts, movable sidewalks that give an opportunity to create the high-comfort space for the physically challenged people. Thus, good implementation of such spaces is the result of collaboration of different spheres of design - urban, landscape, ecological, ergonomics and graphic.

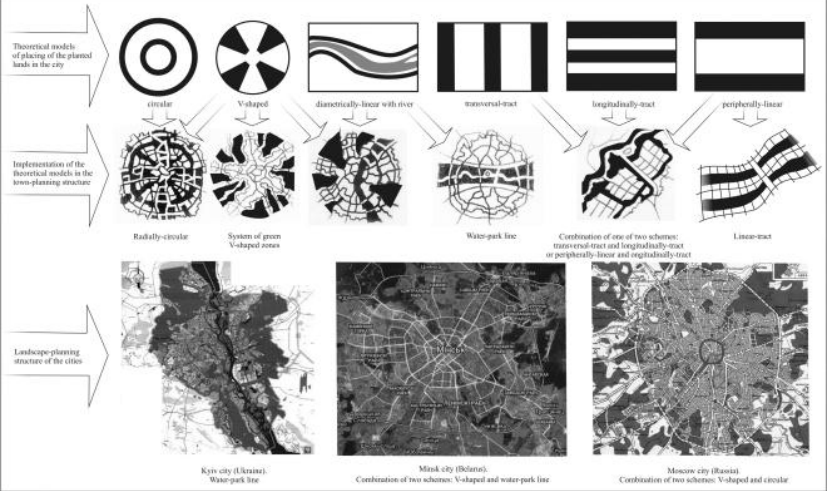

Fig. 5: Theoretical models of placing of the planted lands in the city and their implementation in the town-planning structure (according to [4]).

\section{Varieties of Modern Urban Linear Land- scape Spaces}

The urban linear landscape spaces have the basic recreational loading that is why they envisage the slow rate of movement and perception by visitors. They differ in some way from the fast traffic, and allow to fix attention on the particular details. Therefore basic visitors of linear landscape spaces are pedestrians which move at slow rate, or simply have a rest in nature's lap. "Slow of movement engenders interest in detail. When of we are in a hurry we tolerate few delays, but it moving leisurely, we welcome deflection and distraction. We of have little interest in motion and take pleasure instead in things seen or experienced" [1, p. 135]. Organization of their territory is effected on the basis of laws of deep spatial composition and environment approach. Basic events develop by a certain scenario along a principal composition axis on which the visual pictures of space are slid on. Such scenographical successive visual perception is characteristic both for daily and night life of the urban linear pedestrian spaces.

Among a number of the planted lands of new cities the authors educe the most widespread varieties of linear landscape spaces linear parks and public gardens, embankments, boulevards, parkways. All these landscape objects passed through the evolutional, assumed prominent features and became the integral constituent in the modern town-planning structure. Each of them plays an important role in the town and its habitant's activity and deserves particular attention from the side of scientists.

\subsection{Linear Parks}

A linear park is the territory of the extended form intended for rest with the mainly natural planting formed by means of facilities of landscape-plan organization. In the hierarchy of linear landscape spaces they are distinguished by the large extended physical parameters and placing in the town-planning system (Fig 6). The linear placing of green plantations is used depending on natural or plan town-planning terms. For example, territories created in the system of water-park lines. That is to say the waterway of city as rivers and channels with existent natural surroundings gave a push for creation of these objects. This is confirmed by linear green arrays along irrigational channels in Tashkent (Uzbekistan), by a belt of green plantations along the channel in Riga (Latvia). Such park territories are arranged in parallel to the waterways, along their perimeter. These linear landscape formations form new ecological corridors. They pass in parallel the water-edge, unite central districts of the city, provided the functional park filling.

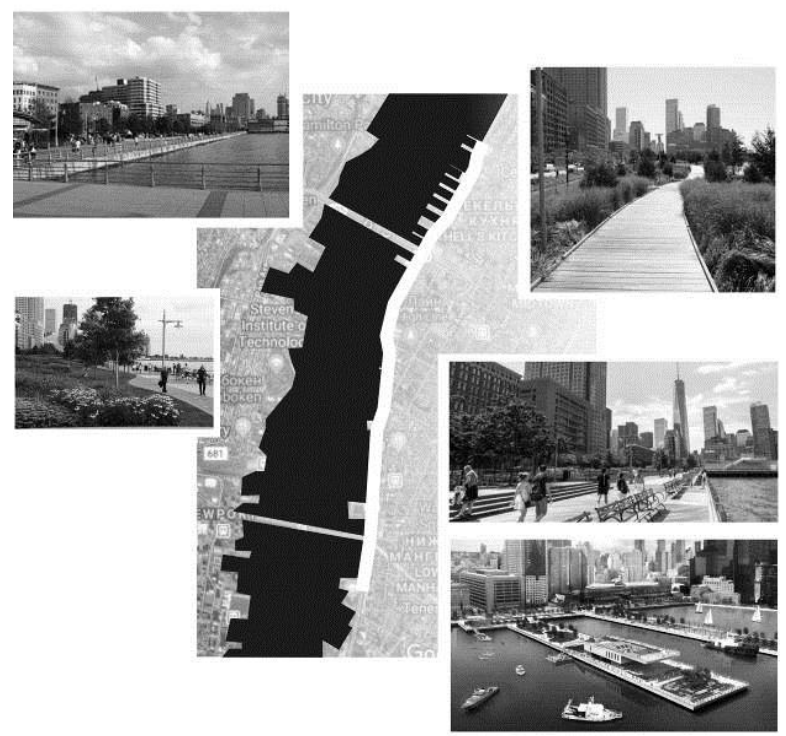

Fig. 6: Beautiful views of Hudson River Park (USA).

Composition-spatial organization of linear park represents a vividness in its central part and natural character of other areas. Formation of such park is based on the laws of deep composition. Development is effected in central part along the main composition axis. Essentially its role is represented by natural axis - rivers, channels, canyons. Water elements serve as important forming factor in the spatially-subject environment of a park. The degree of intercommunication of reservoirs and the whole territory of park is determined by its landscape-hydrological descriptions, sizes and collective intention of authors. Indicative use of horizontal plane of water surfaces of ponds and quiet flow of rivers is typical against the plastic-deflected relief and hummock-andhollow topography. Therefore the spatially-subject environment of linear parks is developed in close relation to reservoirs. The decoratively-aesthetic qualities of water play essential role in organization of composition of the park territory. They are the equivalent constituents of a composition (as that of relief, plants and small architectural forms).They are incorporated by the general composition-landscape conception of the whole park territory.

In small linear parks the role of main composition axis can be executed by the open-space such as avenue, pedestrian walkway. Such space is considered as the open-space due to the use of new types of a landscape-plan organization of park territories - avenues, skirts, parterres, lawns, flower-gardens, cascades and others like that.

Analysis of the urban linear parks showed that organization of their territories is effected with application of the clear functional zoning. The zones of the intensive use and quiet rest are distinguished. Landscapes of open and closed spaces are developed on the wide and long objects under researches, freestanding and group plantings, interesting landscape pictures are created. Zone of the intensive use in such parks is organized close to the objects of cultural value, aqueous-sport grounds and common descents to water. The object and spatial environment of this zone consists of the architectural objects, small architectural forms, facilities of urban design, water elements and vegetable compositions that have mainly the character of open area (parterres, lawns, flowergardens, decorative stony compositions), stippling and design of paving. The calm recreation area is characterized by presence of forums, quiet spots, promenade paths and others things like that. Vegetable components (various wood-shrub and flowers compositions, lawns), haptic sculptural compositions, urban furniture take 
an active part in development of object and spatial environment of this zone.

Investigations by the authors showed that development of the object and spatial environment of linear parks took place with the observance of the following ways:

- interchange of the closed and open spaces with opening of a perspective for a waterway (or central composition axis);

- maximal use of water (if available) in the planning structure of park namely: exit piers, artificial peninsulas on water surface;

- application of plastic, non-standard conceptions for layout of territories, active usage of geoplastic;

- use of new ecological materials;

- $\quad$ application of various urban furniture, their including in the structure of terrene, accenting by color and form.

Depending on placing of linear parks in the layout structure of a city their composition-planning organization may be subject to regular and landscape conceptions. The new conceptions of objects under research succeed the natural forms with free organization of space and picturesque grouping of vegetable forms.

\subsection{Embankments}

An embankment is a shore, reinforced by retaining wall of corresponding construction such as trestle made from stone, concrete, reinforced concrete and other materials that provide it with the required form.

At the present day embankments have the forms of the developed layout - three-D complexes close to a basin, they occupy considerable territory, play an important recreational role and are the place of rest of city folk (Fig 7).They are directly related to urban building and aquatorium. The complex of embankments includes public building, housing building, natural or artificially created riverside landscape and also underground and surface engineering constructions, communications and equipments. Embankments create favorable conditions for pedestrians. Their green corridors stimulate ventilation of urban development. View of the cities, situated on banks of large rivers, pools, seas in a great deal depends on the attractiveness of embankments.

The painterly-aesthetic appearance of embankments inspired the not single generation of artists. For many artists embankments became the central theme of their work. G. Ostroumova-Lebedeva represented the embankments of Saint Petersburg (Russia) in hundreds of engravings, lithographies, water-colours. Her French contemporary A. Markes always leased the workshops overlooking on Seine, whose bridges and embankments were the leading theme of his pictures.

Investigation of embankments as one of types of the linear landscape spaces of city allowed the authors to classify them after following conceptions:

- $\quad$ town-planning location - central (one-sided, bilateral, circular, combined), peripheral (one-sided, bilateral, falcate) and port (for example, central embankment in Toronto, Canada; port embankment of Landunsbruken, Hamburg, Germany; peripheral Hornsbergs Strandpark, Stockholm, Sweden);

- geographical - ocean, marine, lacustrine, river, stream (for example, ocean embankment at Capacabana Beach, Rio de Janeiro, Argentina; marine in Alushta, Alushta, Ukraine; the river English embankment in Saint Petersburg, Russia; stream embankment in Seoul, South Korea);

- building - one-tier, two-tier, many-tier (for example, two-tier embankments, Netherlands Utrecht; embankment of Croisette, Cannes, France; many-tier embankment along the stream of Cheonggyecheon, Seoul, South Korea);

- $\quad$ geometrical- linear, point, metrical systems (for example the figured embankment of park Aterro do Flamengo, Rio de Janeiro, Brazil; system of metrical embankments along Mos- cow river, Moscow, Russia; point embankments of many resort cities);

- $\quad$ structural - with a vertical hydrotechnical retaining wall, slants, half-slants, bastard mansory (embankments with slants in Rurort, Germany, and Luxemburg, Luxemburg; embankments with a vertical wall in Saint Petersburg, Russia);

- $\quad$ aesthetic level - festive, specific, operative (for example, Palace embankment, Saint Petersburg, Russia; specific embankments in Salzburg, Austria; operative embankment sat seaports of Odessa (Ukraine), Marseille (France), Istambul (Turkey).
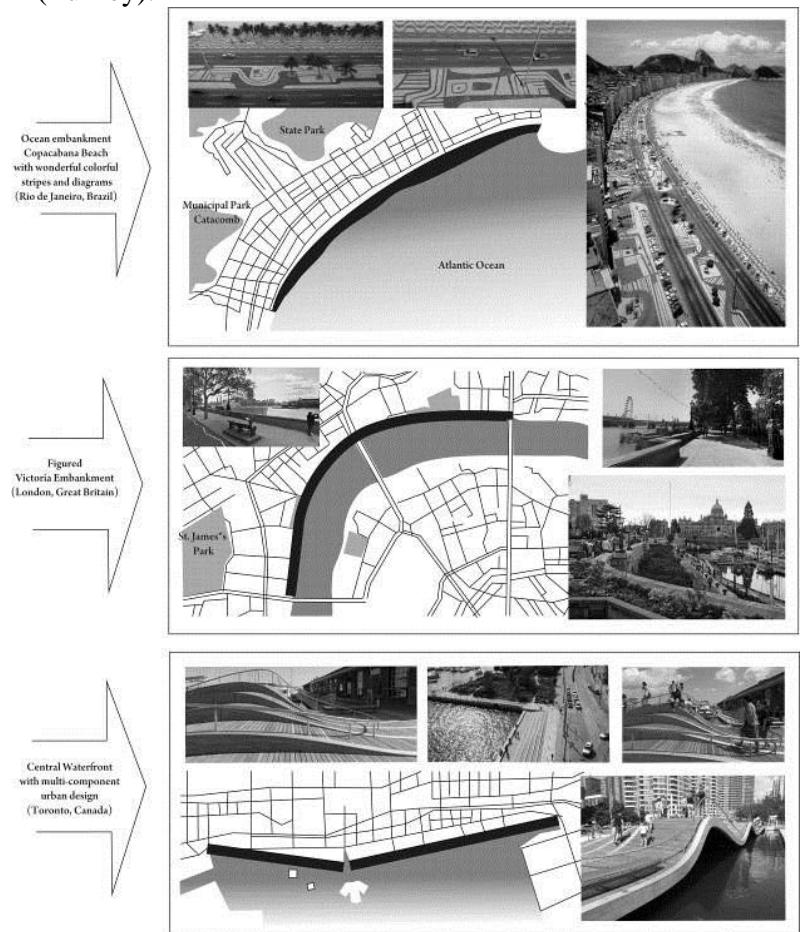

Fig. 7: Some interesting varieties of embankments

The embankment is the important component of the layout and architectural-landscape conception of a city. Its organization closely associated with adjacent urban territory on a compositional level and functionally. Architectural appearance of embankment, its landscaping and site finishing and other components have an important value. The special place in the structure of embankment is occupied by green plantations and small architectural forms. Circumstance that an embankment is visible both from water and from opposite bank while also it is the place of rest and walks of city-folk is taken into consideration.

At the present stage of their development embankments assumed sufficiently expressive vivid implementation due to application of interesting architectural-landscape ways, newest materials and technologies subject to the new requirements of society. World landscape architects and designers are in the permanent search of new facilities of expression of vivid solutions as for coastal territory. From this point of view it is to distinguish the embankments in Riverside-park (New York, USA) and Copacabana Beach PuertoValiarta (Mexico) in Rio de Janeiro (Brazil).The Mexican embankment was converted into an enormous picture. Part of the picture can be observed from the level of eyes of man whilst walking on the embankment, but the whole embankment better and entirely can be observed from a bird eye view or from the overhead floor of the nearest to the embankment multistory building. The New York embankment combines the special architectural structures (industrial building, architectural shadow covers), new infrastructures and landscape spaces (terraces, expansive lawns, recreation areas, barrow-lawns and calm groves). Visitors pass through the typical landscapes of XXI century. Coastal territories of landscape and bays merge with historical railway, portal towers and piers. They were kept by authors as visual references of the industrial past. The Brazilian embankment represents wonderful 
colorful stripes and diagrams, winding and organic, reminiscent the pictures of well-known P. Picasso.

Present time converted embankments into substantial polyfunctional recreational objects with developed cultural-elucidative and sport zones, child's and quiet rest spots with a beach. They become grounds for thematic and seasonal transformations. It is confirmed by numerous examples. To Lyon (France) the embankments of the Rhone river and Sadne river were released from the motor-car parking and transformed into the bicycle and pedestrian paths. In Hague (Netherlands) the embankments opposite the Royal palace is used as an open show-site of modern sculpture. On embankments Seine river (France) from 2002 every summer the beach is to settle down parisians seized-up in city. These embankments at the place of wide overflow of the river are executed as promenade avenues with a numerous access ways to water and quays for the river boats. Visitors promenade, ride on bikes, sit on parapets and steps. In Berlin (Germany) on the Spree riverside opposite the library of Parliament a symbolic cemetery is situated. This is the monument stationed for the people lost at attempt to swim over from East Berlin in the Western part. In Saint Petersburg (Russia) an ambitious project "Europe Embankment" is prepared, that includes Palace of dances, elite housing real estate, offices, hotels and pedestrian embankment. Modern urban embankments are some kind of mix of quiet comfortable rest with active culturalelucidative life of town folk and are the first "visiting card" of maritime towns.

\subsection{Boulevards}

Boulevard is a wide avenue on urban street or embankment for pedestrian motion, usually equipped by benches for rest [10]. According to historical information [11], the first boulevards were laid as early as during the classic epoch. The prime example of boulevards is the "Grands boulevards" in Paris, created during the reign of Louis the Fourteenth. In XIX century because of demolition of old urban walls a number of boulevards appeared on all around the Europe. They became places for promenades or the wide roads planted by trees around on either side. These places run around the city in accordance with the previous location of walls or fortifications. In Paris after demolition of the old defenses of Tier in 1920, Osman developed the second circle of boulevards that are named Externals or Mareshals. In course of time the free use of concept "boulevard" resulted in its synonym such as "avenue". This is confirmed by Osman in his theoretical treatises.

Modern boulevards are able to provide not only recreational and transit functional processes in city but also communication between important functional objects, attraction centers of city, landscape constituents as the so-called "green corridors" [12]. Scientists consider that practically there were two basic plan types of boulevards: the "boulevard circles, created on the city of previous defensive building, of old cities...; and the boulevards for transit pedestrian motion, formed on the basis of the planted trees and shrubs along pedestrian roads and avenues" [12]. The first type of boulevard is characteristic for historical cities - Paris, Vienna, Kracow, Riga, Tallin, Moscow and other. The second variant of boulevards with their inclusion in the structure of urban streets is the most widespread type of the planted trees and shrubs linear spaces for transit pedestrian motion and brief rest.

Boulevards passed their evolutional way and on the modern stage of development have got clear but at the same time various features. Investigation of boulevards as urban linear landscape spaces allows to educe their modern varieties (Fig. 8) by the following descriptions:

- $\quad$ town-planning location - street, centrally street, boulevards-embankments (for example, boulevard of $\mathrm{T}$. Shevchenko, Kyiv, Ukraine; Sea Front in Baku, Azerbaijan; Bulwary Wiślane, Kracow, Poland; Sea Front is Sevastopol, Ukraine);

- geometrical form - rectilinear, broken, rectilinear withupheaval, waved, sectorial, circular (for example, broken Panyansky boulevard in Poltava, Ukraine);
- $\quad$ layout organization - symmetric, asymmetric, with the free location of basic avenue [12];

- dominant elements - aquatic, physiognomic, sculptural with the expressive paving (for example, popular boulevard of T. Shevchenko in Kyiv, Ukraine; boulevard of Avenida-Libertade with the refined paving in Lisbon, Portugal; sculptural boulevard of M. Gogol in Poltava, Ukraine);

- $\quad$ thematic filling - historical, cultural-elucidative, dedicated to the prominent figures (for example, boulevard of Unterderlinden, Berlin, Germany; Sea Front, Odessa, Ukraine; boulevard of I. Kotlyarevsky, Poltava, Ukraine).

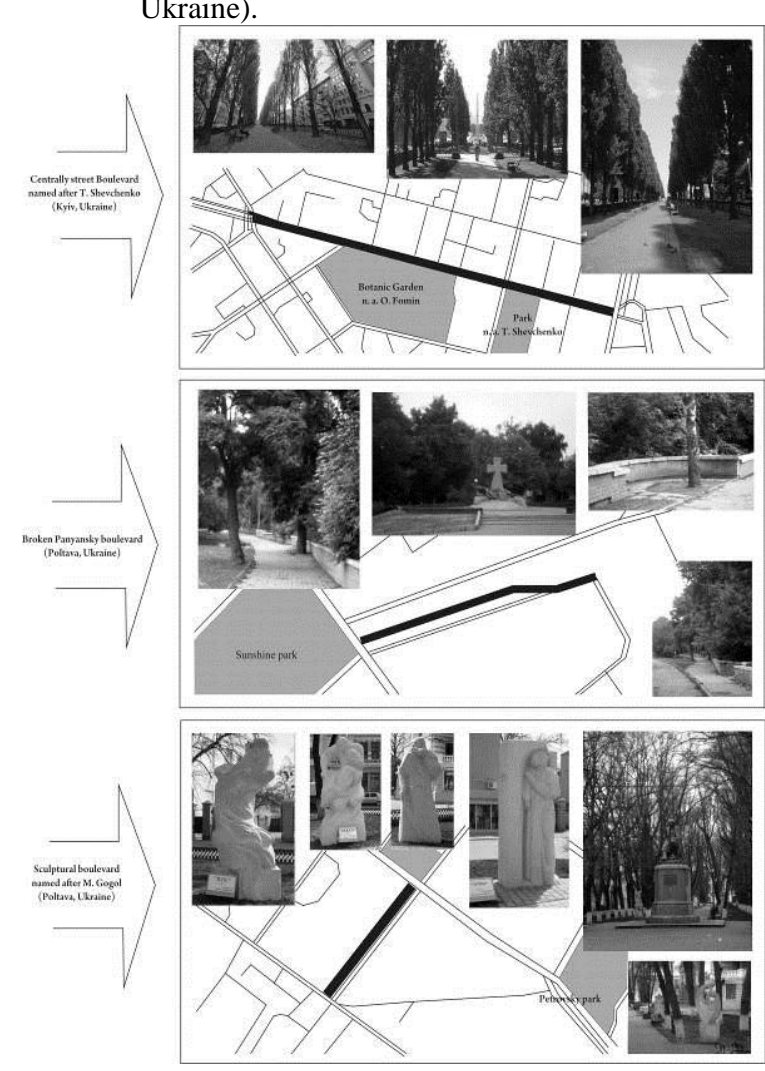

Fig. 8: Some modern varieties of Ukrainian boulevards.

Boulevards are dissociated from transport stream by ordinary green plantations, but at the same time they are an inalienable constituent of the town-planning framework. Due to their organization they allow visitors to concentrate their mind on the aesthetic descriptions. The basic elements of development of boulevards is pedestrian avenue, paths and sites for rest, small chambered spaces, running through the main composition axis, small architectural forms, various elements of greenery (groups, green fencing of bushes, lawns, flower-gardens). Modern boulevards can have the developed layout structure with fountains, pools, trade booths, informative shop-windows-transmitters, decorative planting, monumental compositions. They must be of the high-comfort urban spaces formed considering the ergonomics parameters of certain elements of filling of space and environment in the whole. Creation of harmonious environment of boulevards in the combined scale and implementation promotes introduction in their conception urban furniture and sculptural elements. They are designed to be perceived from near distances and allow haptic contact with visitors.

Depending on the location of boulevards in the urban structure the corresponding approaches to their art-aesthetic organization succeeded. Most festive in this sense are boulevards, created in central districts, near public objects. Some of them conduce visitors to the meaningful cultural centers, entrance groups to the park territories. They, beside the recreational function, carry composition and aesthetic loading. Such boulevards are under characteristically greater exposure of territory because creation of parade parterre 
zones with a number of floral-shrub vegetation, mirrors of reservoirs, regular layout ways of organization with the cut forms of plants. Active influence on quality of art-aesthetic conception has a commonly selected stylish conception of boulevards [13].

\subsection{Parkways}

Parkway is a picturesque recreational highway that links urban and suburban parks (Fig. 9). Development of parkways purchased wide expansion in theory and practically abroad. First such objects have been developed in the USA at the end XIX of century by the landscape architects F. Olmsted and C. Vaux as the separated roads for pedestrians, bicyclists and riders on the landscape territories. Also they introduced the term "parkway" for determination of the abovementioned communications. First parkways were laid exceptionally as communication ways through the recreational territories, connecting attractive landscape areas, considerable objects of city and, even, separate cities in against each other. Mainly they are the direct routes laid across different areas, in most of them the entrance for freight transport, busses, noncommercial transportations is forbidden. The first parkway was deemed the Eastern Parkway (Brooklyn) in New York (USA) projected in 1870. It connects two large landscape zones - New York Botanical garden and ritual park Evergreens.

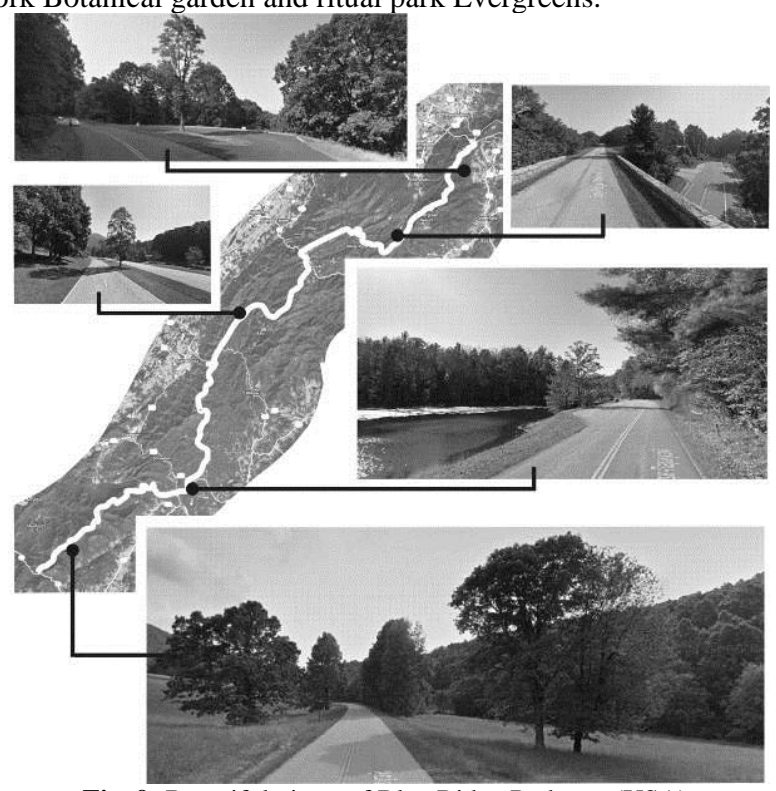

Fig. 9: Beautiful views of Blue Ridge Parkway (USA).

At the beginning XX of century, meaning of the term word was extended. The name "parkway" received recreational motorways with slow motion of vehicles. In course of time some objects under research became paid for drivers. Certain historical, social and economic events resulted in improvement of parkways by application of equipping with modern amenities and facilities of landscape design, provided that not only within the limits of traveling way but also on the adherent territories. This process resulted in appearance of landscape objects with the expressed linear composition development. As examples - Delavare Park, Buffalo, USA; Mystic Valley Parkway, Boston, USA. The distinctive feature of parkways of this period was isolation from commercial displays and advertisement elements, even then, when transport way run through a settlement. All attention was spared to the road and its art-aesthetical conception of adherent landscape territories.

Actually a lot of parkways have one highway with the special emblems - cognitive signs that inform about strengthening of feeling of isolation of drivers from the urbanized world, they are under limited access of commercial traffic (except for trucks).

There is the whole system of parkways in the USA (New York State Parkway System) that is controlled from the side of the state The system of parkways was built, to provide a direct way from New York to the State park Herriman. It is worthy to note the refined art-aesthetical organization of some parkways, in particu- lar - Blue Ridge Parkway (The USA) and Atlantic Ocean Road (Norway). The first is the national parkway in the USA, it is the longest linear park of America, created along a main range of mountains, - Blue Ridge. The second is a road which takes over eight kilometers that is laid in the most picturesque and unprotected natural area of Norway. Parkway connects the inland of country with a number of islands by bridges (dikes, viaducts), among them the greatest and the most spectacular one is the Storseisundet Bridge.

In course of the investigational period the parkways evolved from an ordinary object for communication to the linear landscape formation with the excellent equipping with modern amenities. They are used in the names of many American and Canadian waysmotorways as the basic itineraries laid through national parks, picturesque places of several cities and state in the whole.

\section{Conclucions}

The urban environment of existence of modern human must constitute the harmonious concord of the urbanized informative space, innovative technologies and territories planted with trees and shrubs. Maintenance of the existent green "lungs" of city and improvement its system green territories is one of the important and at the same time perspective trends of increase of a culturalaesthetic potential of city, improvement of its architecturallandscape environment and ecological microclimate. Linear landscape spaces are the integral constituents of these processes. They are a powerful landscape source, where it is possible in the truest sense of the word; they make sculptural individual face of urban spaces, creating accents where in they have been set by nature. Not single conceptions on forming the functional framework of a city, its layout structure and infrastructure in the whole are not perfect without the integrated inclusion of features of its natural environment.

Investigation of linear landscape spaces resulted in realization of their meaningfulness not only in development of the urban layout structure but also in the vital functions of city and his habitants in the whole. It is shown up:

- $\quad$ at town-planning level - refinement and development of the architectural-landscape urban structure, adjusting its transport infrastructure; maintenance of natural planning axes, underlining of expressiveness of their authentic fragments;

- $\quad$ at the art-aesthetical level - in softening of the architectural urban matrix by the system of planting of greenery, provision of landscape variety to particular linear spaces; in assistance while underlining and exposure of valuable architectural objects; in provision of coloristic expressiveness to a city;

- $\quad$ at social level - in satisfaction of daily human needs during a brief rest in natural environment; in provision of communication dwellers in linear parkas, public gardens, boulevards and embankments; in satisfaction of the folk needs in various in cultural-educational arrangements, performances, which are based on the linear landscape spaces.

For the ordinary urbanite the linear landscape space is a source of positive emotions from the refined vegetable compositions, their aroma, impression from the palpitation of leaves and purl of water. It is the place of meeting and parting, allowing easily to strike up an acquaintance with someone and be calmly secluded in a natural urban environment. At the same time, this is the stationary place of urban attractiveness, epicenter of bright emotions and stormy passions. This is another example of development of landscape harmonious environment, where people feel happy themselves in the city of XXI century. 


\section{Acknowledgement}

Scientists are kindly acknowledged for the permission to study linear landscape spaces in the planning structure of the city.

\section{References}

[1] Simonds J. O., Landscape Architecture. The shaping of man's natural environment, F.W. Dodge Corporation, New York, NY, 1961, $405 \mathrm{p}$.

[2] Lynch K., Image of the city, Cambridge Massachussettes, MIT Press, 1960, $194 \mathrm{p}$

[3] Brinckmann A. E., Plastik und Raum als Grundformen künstlerischer Gestaltung, R. Piper, 1922, 80 p.

[4] Rodychkyn I.D., Landscaping: A short guide of architect, Kyiv, Budivelnyk, 1990, 334 p

[5] Verhunov A.P., Architectural and landscape organization of a large city, Leningrad, Stroiyzdat, 1982, 134 p.

[6] Sitte C., Der Städte-Bau nach seinen künstlerischen Grundsätzen Ein Beitrag zur Lösung moderner Fragen der Architektur und monumentalen Plastik unter besonderer Beziehung auf Wien, Leipsig, Wien, C. Graeser \& Co., 1901, 183 p.

[7] Belov M.Y., The design of pedestrian street. Extended abstract of candidate's thesis. Moscow, 2012, 23 p., available online: http://cheloveknauka.com/dizayn-peshehodnoy-ulitsy, last visit: 09.04.2018.

[8] Bunin A., Savarenskaya T., The history of urban art, Volume 2 , Moscow, Stroyizdat, 1979, 406 p.

[9] Merlin P., New cities. Region and urban planning, Moscow, Progress, $1975,255 \mathrm{p}$.

[10] Marder A.P., Arcitecture. Short dictionary-directory, Kyiv, Budivelnyk, 1995, 334 p.

[11] Merlin P., Francoise Choay. Dictionnaire de l'urbanisme et de l'amenagement, Quadrige dicos poche, 2010, $880 \mathrm{p}$.

[12] Rodichkin I.D., Short Architect Guide: landscape architecture, Kyiv, Budivelnyk, 1990, 336 p.

[13] Shevchenko L., Chebina O., Boulevard as a type of urban linear space. Historical boulevards of Poltava (Ukraine) and Mons (the Kindom of Belgium), Architectura \& Urbanismus, Bratislava, Institute of Construction and Architecture Slovak Academy of Sciences, 2015, pp. 154-171. (ISSN 0044-8680. Type: FAI). 